\title{
STUDY OF THE POSSIBLE HEPATOPROTECTIVE EFFECT OF PROPOLIS AGAINST THE HEPATOTOXIC EFFECT OF ATORVASTATIN IN ALBINO RATS
}

\author{
Ahmed A. Abdelsameea, Laila A. Mahgoub and Samar M. Abdel Raouf* \\ Departments of Pharmacology and Pathology* Faculty of Medicine-Zagazig University
}

\begin{abstract}
Background: Liver injuries induced by various hepatotoxins have been recognized as a major toxicological problem for years. 3-Hydroxy-3-methyglutaryl coenzyme A (HMG-CoA) reductase inhibitors (statins) are widely used drugs to reduce cholesterol levels and prevent coronary heart disease. One of the adverse effects of statins is affection of the liver functions with increased transaminases levels. Propolis is collected by honeybees from various plant sources. It was found to have hepatoprotective activity.

Aim: The present study evaluated the possible hepatoprotective effect of propolis against hepatotoxic effect of atorvastatin in albino rats.

Methods: Propolis in doses of 50 and $100 \mathrm{mg} / \mathrm{kg}$ were administered one hour before atorvastatin in doses of 20 and $80 \mathrm{mg} / \mathrm{kg}$ daily, orally for one month. Hepatoprotective effect of propolis was evaluated by measuring levels of ALT and AST in the serum and SOD and CAT in the liver homogenate. The histopathological studies were also studied to support the biochemical parameters.

Results: Atorvastatin in a dose of 20 and $80 \mathrm{mg} / \mathrm{kg}$ produced dose-dependent, significant elevation of ALT, AST, SOD, CAT and hepatocyte degeneration. Administration of propolis 50 and $100 \mathrm{mg} / \mathrm{kg}$ produced dose-dependent, significant reduction of the previous biochemical parameters and also prevented atorvastatin induced alterations in histoarcheticture of liver in a dose dependent manner.

Conclusion: Propolis protected the liver from the toxic effect of atorvastatin. The hepatoprotective effect of propolis may be due to its strong antioxidant activity.
\end{abstract}

\section{INTRODUCTION}

$\mathbf{D}$ rug-induced liver injury (DILI) accounts for $9.5 \%$ of all suspected adverse drug reactions. Pre-clinical drug trials detect common DILI, but many are rare and detected only during postmarketing surveillance. ${ }^{1}$ DILI is the most common reason for discontinuation of a new drug's development and withdrawal of an established one. DILI accounts for $14 \%$ of all cases of acute liver failure and is the leading cause for patients to be listed for super-urgent liver transplantation. ${ }^{2}$

It is well established that 3-hydroxy-3methyglutaryl coenzyme A (HMG-CoA) reductase inhibitors (statins) reduce cholesterol levels and prevent coronary heart disease (CHD). The principal adverse effects of statins are myopathy, and marked increase in transaminases. ${ }^{3}$ Patients may present with malaise, anorexia, and precipitous decreases in LDL. ${ }^{4}$

Propolis is a complex resinous hive product collected by bees from several plants, showing a very complex chemical composition. It has been used as a health drink and is extensively used in food to improve health and prevent diseases such as heart diseases and diabetes. It has also been used in the folk medicine due to its hepatoprotective activity. ${ }^{5}$ In the last years, there is a renewed interest in the biological activities of propolis. It has therapeutic properties, such as antimicrobial, anti-inflammatory, antioxidant, immunomodulatory and antitumour activities, among others. ${ }^{6}$ Propolis contains large amounts of antioxidative compounds, such as caffeic acid, ferulic acid and caffeic acid phenethyl ester. ${ }^{7}$ For this reason it attracts the attention of scientists to search for new therapetuic usage. Antioxidants play an important role in inhibiting and scavenging free radicals, thus providing protection to humans against infectious and degenerative diseases. $^{8}$

The aim of the present study was to evaluate the possible hepatoprotective effect of propolis against hepatotoxic effect atorvastatin in albino rats.

\section{MATERIALS AND METHODS}

Drugs and chemicals: Atorvastatin powder (EIPICO, Egypt), Ether anesthesia (El-Naser company, Egypt) propolis powder (Honey centers, Saint Kathreen, Egypt), Suspending agent [gum tragecanth] (El-Gomhoria company, Egypt). Propolis $(50$ and $100 \mathrm{mg} / \mathrm{kg}$ ) was administered to rats by preparing fresh suspension in distilled water and adding suspending agent [gum tragecanth] in a ratio of $4: 1$ respectively and shaked well before giving it orally by gastric gavage. ${ }^{9}$

Atorvastatin doses (20 and $80 \mathrm{mg} / \mathrm{kg}$ ) in $1 \mathrm{ml}$ distilled water orally by gastric gavage daily. ${ }^{10}$

Animals: Adult albino rats of either sex, weighing 190-220gm, were used in these experiments. The animals were kept in standard animal house. Food and water were available ad labitum.

All experimental protocols were approved by the ethics committee of Zagazig University.

The experimental design: 56 albino rats were divided into 7 groups, eight rats for each:

Group I: The rats were administered the suspending agent [gum tragecanth] for propolis 
orally in a dose of $25 \mathrm{mg} / \mathrm{kg}$ in $1 \mathrm{ml}$ distilled water daily for 1 month.

Group II: Each rat of this group was administered atorvastatin orally, in a dose of $20 \mathrm{mg} / \mathrm{kg}$ in $1 \mathrm{ml}$ distilled water daily for $1 \mathrm{month}$.

Group III: Each rat of this group was administered propolis orally in a dose of $50 \mathrm{mg} / \mathrm{kg}$ as $1 \mathrm{ml}$ suspension, then after one hour each rat was administered atorvastatin orally in a dose of $20 \mathrm{mg} / \mathrm{kg}$ in $1 \mathrm{ml}$ distilled water daily for $1 \mathrm{month}$.

Group IV: Each rat in this group was administered propolis orally, $100 \mathrm{mg} / \mathrm{kg}$ body weight then, after one hour atorvastatin was administered orally in a dose of $20 \mathrm{mg} / \mathrm{kg}$ in $1 \mathrm{ml}$ distilled water daily for 1 month.

Group V: Each rat was administered atorvastatin orally in a dose of $80 \mathrm{mg} / \mathrm{kg}$ in $1 \mathrm{ml}$ distilled water daily for 1 month.

Group VI: Each rat of this group was administered propolis orally in a dose of $50 \mathrm{mg} / \mathrm{kg}$ as $1 \mathrm{ml}$ suspension, then after one hour each rat received atorvastatin orally in a dose of $80 \mathrm{mg} / \mathrm{kg}$ in $1 \mathrm{ml}$ distilled water daily for $1 \mathrm{month}$.

Group VII: Propolis in a dose of $100 \mathrm{mg} / \mathrm{kg}$ as $1 \mathrm{ml}$ suspension was administered orally to each rat in this group, then after one hour atorvastatin was administered in a dose of $80 \mathrm{mg} / \mathrm{kg}$ in $1 \mathrm{ml}$ distilled water daily for 1 month.

\section{Biochemical studies:}

At the end of treatment period (30 days), blood samples were collected from retro bulbar venous plexus by very fine heparinized glass tubes. Blood samples were centrifuged $\left(5000 \mathrm{~g} ; 15 \mathrm{~min}\right.$ at $\left.4^{\circ} \mathrm{C}\right)$ and the clear supernatants were removed to estimate the serum alanine aminotransferase (ALT) and aspartate aminotransferase (AST). Blood samples were drawn by puncturing retroorbital venous sinus, centrifuged and serum was isolated for estimation of transaminases AST \& ALT. ${ }^{11}$

\section{Estimation of serum ALT and AST:}

Principle: Colorimetric determination of AST or ALT activities.

Reagents: AST Buffer substrate: Phosphate buffer $\mathrm{pH}$ 7.5(100 mmol/L), Aspartate (100 $\mathrm{mmol} / \mathrm{L}), \alpha$-Ketoglutarate $(2 \mathrm{mmol} / \mathrm{L})$. ALT Buffer substrate: Phosphate buffer pH 7.5 (100 $\mathrm{mmol} / \mathrm{L})$, Alanine $(200 \mathrm{mmol} / \mathrm{L}), \alpha$-Ketoglutarate (2 mmol/L). Color Reagent: 2, 4 dinitrophenylhydrazine $1 \mathrm{mmol} / \mathrm{L}$. Standard pyruvate $2 \mathrm{mmol} / \mathrm{L}$. Additional reagent: (available on request) Sodium hydroxide $0.4 \mathrm{~N}$.

Procedure: Mix, Wait $5 \mathrm{~min}$. Measure the absorbances at $505 \mathrm{~nm}(490-520 \mathrm{~nm})$ against distilled water using cuvettes $1 \mathrm{~cm}$ light path. The color is stable for one hour. Linearity for AST up to 150 units $/ \mathrm{ml}$ and for ALT up to 120 units $/ \mathrm{ml}$.

Calculation: Calculate the number of units / $\mathrm{ml}$ of AST and ALT of sample using the standard curve. Liver Homogenates

Prior to dissection, perfuse liver with a phosphate buffered saline solution, $\mathrm{pH} 7.4$ containing 0.16 $\mathrm{mg} / \mathrm{ml}$ heparin to remove any red blood cells and clots.

Homogenize the liver in $5-10 \mathrm{ml}$ cold buffer (i.e., $50 \mathrm{mM}$ potassium phosphate, $\mathrm{pH} 7.5 .1 \mathrm{mM}$ EDTA) per gram liver. Centrifuge at 100,000 x g for 15 minutes at $4{ }^{\circ} \mathrm{C}$. Remove the supernatant for assay and store on ice. If not assayed on the same day, freeze the sample at $-80^{\circ} \mathrm{C}$. The sample will be stable for at least one month.

\section{Estimation of SOD and CAT activities in the} liver homogenate:

SOD activity was measured by the inhibition of pyrogallol autooxidation. ${ }^{12}$ Briefly, $200 \mu \mathrm{l}$ of sample was mixed with $750 \mu \mathrm{l}$ cacodylic buffer (50 mM Tris-HCL, $50 \mathrm{mM}$ cacodylic acid, I mM diethylenetriamine pentacetic acid, $\mathrm{pH}$ 8.2) and $200 \mu \mathrm{l}$ pyrogallol $(2 \mathrm{mM})$. Absorbance was monitored at $420 \mathrm{~nm}$ for $3 \mathrm{~min}$. one unit of SOD activity was defined as the amount of enzyme required to produce a $50 \%$ inhibition of pyrogallol auto-oxidation.

Catalase activity was measured by monitoring enzyme- catalyzed decomposition of $\mathrm{H}_{2} \mathrm{O}_{2}$. Briefly, a solution of $\mathrm{H}_{2} \mathrm{O}_{2}$ was added to test tubescontaining samples, water blank, and an $\mathrm{H}_{2} \mathrm{O}_{2}$ standard solution (Standard). After $3 \mathrm{~min}$ incubation, the enzymatic reaction was terminated by the addition of $\mathrm{H}_{2} \mathrm{SO}_{4} . \mathrm{KMnO}_{4}(1.4 \mathrm{ml})$ was added to each tube, vortexes and absorbance recorded at $480 \mathrm{~nm}$. One unit of catalase activity is defined as $\mathrm{k} /(0.00693)$, where $\mathrm{k}=\log \left(\mathrm{S}_{\mathrm{O}} / \mathrm{S}_{2}\right)$ $(2.3 / \mathrm{t}), \quad \mathrm{S}_{\mathrm{O}}$ is absorbance of standard minus absorbance of blank, $S_{2}$ is absorbance of standard minus absorbance of sample and $\mathrm{t}$ is time interval. ${ }^{13}$

Histopathological study: After the animals were anesthetized by ether, the liver of each animal was immediately dissected out to be processed for light microscope to show the toxic effect of atorvastatin and the protective effect of propolis and to compare with normal liver. Samples from the liver were fixed in $10 \%$ formalin, embedded in paraffin blocks and processed for preparation of sections. Sections were stained with hematoxylin and eosin. ${ }^{14}$

Statistical analysis: The obtained data were tabulated as means \pm SE. Comparison between different groups were made using one way analysis of variances (one-way ANOVA) 
followed by post-hoc (least significant difference LSD) test. The differences were considered to be significant when $p<0.05$. Statistical Package of Social Sciences (SPSS) computer software (version 14) was used to carry out the statistical analysis.

\section{RESULTS}

Effect of oral administration of atorvastatin $[20 \mathrm{mg} / \mathrm{kg}]$ alone and in combination with propolis suspension in doses of [50 and $100 \mathrm{mg} / \mathrm{kg}$ ] for one month on the serum levels of AST\& ALT and the activity of SOD\& CAT in liver homogenates in albino rats.

In the control group where every rat was given distilled water $1 \mathrm{ml}$ with suspending agent (gum tragecanth $25 \mathrm{mg} / \mathrm{kg}$ ) orally daily for one month, the levels of AST, ALT were $117 \pm 8.551$ and $57 \pm 4.334 \mathrm{IU} / \mathrm{L}$ respectively. Administration of atorvastatin in a dose of $20 / \mathrm{kg}$ for one month caused significant elevation of AST and ALT to $152 \pm 9.242$ and $68 \pm 4.573 \mathrm{IU} / \mathrm{L}$. Administration of propolis in a dose of $50 \mathrm{mg} / \mathrm{kg}$ plus atorvastatin $20 \mathrm{mg} / \mathrm{kg}$ for one month caused reduction of the elevated AST and ALT to $125 \pm 7.313$ and $59 \pm 3.962 \mathrm{IU} / \mathrm{L}$ respectively which were insignificant from the control levels but significantly reduced in relation to values of atorvastatin group. Oral administration of propolis in a dose of $100 \mathrm{mg} / \mathrm{kg}$ plus atorvastatin $20 \mathrm{mg} / \mathrm{kg}$ for one month caused reduction of the elevated AST and ALT to $119 \pm 8.774$ and $56 \pm 4.942 \mathrm{IU} / \mathrm{L}$ respectively which were significantly reduced in relation to values of atorvastatin group but insignificant from the control levels.

In the liver homogenates, SOD and CAT activities in the control group were $1.564 \pm 0.128$ and $4.986 \pm 0.382$ which were significantly elevated after administration of atorvastatin in a dose of $20 / \mathrm{kg}$ for one month to $1.889 \pm 0.147$ and $5.502 \pm 0.476$ respectively. Administration of propolis in a dose of $50 \mathrm{mg} / \mathrm{kg}$ plus atorvastatin $20 \mathrm{mg} / \mathrm{kg}$ for one month caused significant reduction of the elevated SOD and CAT activities to $1.402 \pm 0.098$ and $5.012 \pm 0.364$. With administration of propolis in a dose of $100 \mathrm{mg} / \mathrm{kg}$ plus atorvastatin $20 \mathrm{mg} / \mathrm{kg}$ for one month, SOD and CAT activities were significantly reduced to $1.136 \pm 0.092$ and $5.112 \pm 0.411$ (Table 1).

Table (1): Effect of oral administration of atorvastatin $[20 \mathrm{mg} / \mathrm{kg}]$ alone and in combination with propolis suspension in doses of [50 and $100 \mathrm{mg} / \mathrm{kg}$ ] for one month on the serum levels of AST\& ALT and the activities of CAT\& SOD in liver homogenates in albino rats.

\begin{tabular}{lllll}
\hline Control $(\mathrm{n}=8)$. & $\begin{array}{l}\text { Atorvastatin } \\
(20 \mathrm{mg} / \mathrm{kg})(\mathrm{n}=8)\end{array}$ & $\begin{array}{l}\text { Atorvastatin } \\
(20 \mathrm{mg} / \mathrm{kg})+ \\
\text { Propolis } \\
(50 \mathrm{mg} / \mathrm{kg})(\mathrm{n}=8)\end{array}$ & $\begin{array}{l}\text { Atorvastatin } \\
(20 \mathrm{mg} / \mathrm{kg})+ \\
\text { Propolis } \\
(100 \mathrm{mg} / \mathrm{kg})(\mathrm{n}=8)\end{array}$ \\
\hline AST & $117 \pm 8.551^{\mathrm{A}}$ & $152 \pm 9.242^{\mathrm{B}}$ & $125 \pm 7.313^{\mathrm{A}}$ & $119 \pm 8.774^{\mathrm{A}}$ \\
\hline ALT & $57 \pm 4.334^{\mathrm{A}}$ & $68 \pm 4.573^{\mathrm{B}}$ & $59 \pm 3.962^{\mathrm{A}}$ & $56 \pm 4.942^{\mathrm{A}}$ \\
\hline SOD & $1.654 \pm 0.128^{\mathrm{A}}$ & $1.889 \pm 0.147^{\mathrm{B}}$ & $1.402 \pm 0.098^{\mathrm{C}}$ & $1.136 \pm 0.092^{\mathrm{D}}$ \\
\hline CAT & $4.986 \pm 0.382^{\mathrm{A}}$ & $5.502 \pm 0.476^{\mathrm{B}}$ & $5.012 \pm 0.364^{\mathrm{A}}$ & $5.112 \pm 0.411^{\mathrm{A}}$ \\
\hline
\end{tabular}

* Means without common superscript capital letters are significantly different $(\mathrm{P}<0.05)$.

$* \mathrm{n}=$ Number of rats

Effect of oral administration of atorvastatin $[80 \mathrm{mg} / \mathrm{kg}]$ alone and in combination with propolis suspension in doses of $[50$ and $100 \mathrm{mg} / \mathrm{kg}$ ] for one month on the serum levels of AST\& ALT and the activities of CAT\& SOD in liver homogenates in albino rats.

In control group where every rat was received distilled water $1 \mathrm{ml}$ with the suspending agent (gum tragecanth $5 \mathrm{mg}$ ) orally daily for one month, the levels of AST, ALT and cholesterol were $117 \pm 8.554$ and $57 \pm 4.331 \mathrm{IU} / \mathrm{L}$ respectively. Administration of atorvastatin in a dose of $80 / \mathrm{kg}$ for one month caused significant elevation of AST and ALT to $247 \pm 15.575$ and $118 \pm 9.141 \mathrm{IU} / \mathrm{L}$. Administration of propolis in a dose of $50 \mathrm{mg} / \mathrm{kg}$ plus atorvastatin $80 \mathrm{mg} / \mathrm{kg}$ for one month caused significant reduction of the elevated AST and ALT to $195 \pm 12.216$ and $89 \pm 7.573$ IU/L respectively. Oral administration of propolis in a dose of $100 \mathrm{mg} / \mathrm{kg}$ plus atorvastatin $80 \mathrm{mg} / \mathrm{kg}$ for one month caused significant reduction of the elevated AST and ALT to $129 \pm 7.526$ and $63 \pm 4.343 \mathrm{IU} / \mathrm{L}$ respectively and were insignificant from the control levels.

SOD and CAT activities in the liver homogenates in the control group were $1.564 \pm 0.128$ and $4.986 \pm 0.382$ which were significantly elevated after administration of atorvastatin in a dose of $80 / \mathrm{kg}$ for one month to $1.978 \pm 0.126$ and $5.813 \pm 0.409$ respectively. Administration of 
propolis in a dose of $50 \mathrm{mg} / \mathrm{kg}$ plus atorvastatin $20 \mathrm{mg} / \mathrm{kg}$ for one month caused significant reduction of the elevated SOD and CAT activities to $1.863 \pm 0.112$ and $5.007 \pm 0.365$. With administration of propolis in a dose of $100 \mathrm{mg} / \mathrm{kg}$ plus atorvastatin $20 \mathrm{mg} / \mathrm{kg}$ for one month, the SOD and CAT activities were significantly reduced to $1.581 \pm 0.095$ and $4.889 \pm 0.365$ (Table 2).

Table (2): Effect of oral administration of atorvastatin $[80 \mathrm{mg} / \mathrm{kg}]$ alone and in combination with propolis suspension in doses of [50 and $100 \mathrm{mg} / \mathrm{kg}$ ] for one month on the serum level of AST\& ALT and the activities of CAT\& SOD in liver homogenates in albino rats..

\begin{tabular}{llll} 
Control $(\mathrm{n}=8)$. & $\begin{array}{l}\text { Atorvastatin } \\
(80 \mathrm{mg} / \mathrm{kg})(\mathrm{n}=8) .\end{array}$ & $\begin{array}{l}\text { Atorvastatin } \\
(80 \mathrm{mg} / \mathrm{kg})+ \\
\text { Propolis } \\
(50 \mathrm{mg} / \mathrm{kg})(\mathrm{n}=8) .\end{array}$ & $\begin{array}{l}\text { Atorvastatin } \\
(80 \mathrm{mg} / \mathrm{kg})+ \\
\text { Propolis } \\
(100 \mathrm{mg} / \mathrm{kg})(\mathrm{n}=8) .\end{array}$ \\
\hline $117 \pm 8.554^{\mathrm{A}}$ & $247 \pm 15.575^{\mathrm{B}}$ & $195 \pm 12.216^{\mathrm{C}}$ & $129 \pm 7.526^{\mathrm{A}}$ \\
\hline $57 \pm 4.331^{\mathrm{A}}$ & $118 \pm 9.141^{\mathrm{B}}$ & $89 \pm 7.573^{\mathrm{C}}$ & $63 \pm 4.343^{\mathrm{A}}$ \\
\hline $1.654 \pm 0.128^{\mathrm{A}}$ & $1.978 \pm 0.126^{\mathrm{B}}$ & $1.863 \pm 0.112^{\mathrm{B}}$ & $1.581 \pm 0.095^{\mathrm{A}}$ \\
\hline $4.986 \pm 0.382^{\mathrm{A}}$ & $5.813 \pm 0.409^{\mathrm{B}}$ & $5.007 \pm 0.365^{\mathrm{A}}$ & $4.889 \pm 0.365^{\mathrm{A}}$ \\
\hline
\end{tabular}

* Means without common superscript capital letters are significantly different $(\mathrm{P}<0.05)$.

$* \mathrm{n}=$ Number of rats

\section{Histopathological finding:}

Group I: light microscopic examination of the liver revealed normal lobular architecture. The hepatic lobule was hexagonal in shape, consisting radically arranged cords of doublets of hepatocytes radiating from the central vein. These cords were separated by blood sinusoids and bile canaliculi were present in between the hepatocytes.

Group II: Rats given atorvastatin in a dose of $20 \mathrm{mg} / \mathrm{kg}$ have minimal hepatocyte degeneration (hydrobic degeneration and fatty degeneration) were present. The parenchyma of the liver and the portal area were infiltrated by lymphocytes.

Group III: Rats given atorvastatin in a dose of $20 \mathrm{mg} / \mathrm{kg}$ and propolis in a dose of $50 \mathrm{mg} / \mathrm{kg}$ : the degenerative changes and swelling were lower in comparison to group II. Also the lymphocytic infiltrate were lower.

Group IV: When propolis dose increased to $100 \mathrm{mg} / \mathrm{kg}$, the changes recorded with atorvastatin $20 \mathrm{mg} / \mathrm{kg}$ were reversed; the liver parenchyma was normal and the lymphocytic infiltrations in the portal area disappeared.

Group V: Damage to the liver was found after ingestion of atorvastatin $(80 \mathrm{mg} / \mathrm{kg}$ in $1 \mathrm{ml}$ distilled

Table (3): Effect of oral administration of atorvastatin $[20 \mathrm{mg} / \mathrm{kg}]$ alone and in combination water daily for 1 month). Hepatocyte degeneration and swelling (hydrobic degeneration and ballooning) and fatty degeneration, hepatic parenchyma infiltration by lymphocytes (lytic and confluent necrosis) and the portal area also showed infiltration by mononuclear inflammatory cells with spillover of inflammation into the adjacent parenchyma (interface hepatitis).

Group VI: Rats given atorvastatin in a dose of $80 \mathrm{mg} / \mathrm{kg}$ and propolis in a dose of $50 \mathrm{mg} / \mathrm{kg}$ : hepatic lobular disruption is slightly improved, hepatocyte degeneration and swelling were lower in comparison to group V. Parenchyma and portal tract lymphocytic infiltration were lower than group V

Group VII: Rats given atorvastatin in a dose of $80 \mathrm{mg} / \mathrm{kg}$ and propolis in a dose of $100 \mathrm{mg} / \mathrm{kg}$ : improvements in hepatic histoarchitecture was found, hepatocyte degeneration and swelling were minimal. Parenchymal and portal tract lymphocytic infiltration were much lower than in group V and VI.

So propolis has the ability to reverse atorvastatin histological alterations and this effect is dose dependant.

with propolis suspension in doses of [50 and $100 \mathrm{mg} / \mathrm{kg}$ ] for one month on liver histopathology in albino rats.

\begin{tabular}{llll}
\hline & $\begin{array}{l}\text { Hepatic } \\
\text { histoarchitecture }\end{array}$ & $\begin{array}{l}\text { hepatocyte } \\
\text { degeneration } \\
\text { swelling }\end{array}$ & $\begin{array}{l}\text { Parenchymal and portal tract } \\
\text { and }\end{array}$ \\
\hline Group I & Normal & - & - \\
\hline Group II & Slightly disrupted & ++ & ++ \\
\hline Group III & $\begin{array}{l}\text { Moderately } \\
\text { improved }\end{array}$ & + & + \\
\hline
\end{tabular}


Table (4): Effect of oral administration of atorvastatin $[80 \mathrm{mg} / \mathrm{kg}]$ alone and in combination with propolis suspension in doses of [50 and $100 \mathrm{mg} / \mathrm{kg}$ ] for one month on liver histopathology in albino rats.

\begin{tabular}{llll}
\hline & $\begin{array}{l}\text { Hepatic } \\
\text { histoarcheticture }\end{array}$ & $\begin{array}{l}\text { hepatocyte } \\
\text { degeneration } \\
\text { swelling }\end{array}$ & $\begin{array}{l}\text { Parenchymal and portal tract } \\
\text { lymphocytic infiltration }\end{array}$ \\
\hline Group V & Disrupted & ++++ & ++++ \\
\hline Group VI & Slightly improved & ++ & ++ \\
\hline Group VII & Moderately improved & + & + \\
\hline
\end{tabular}

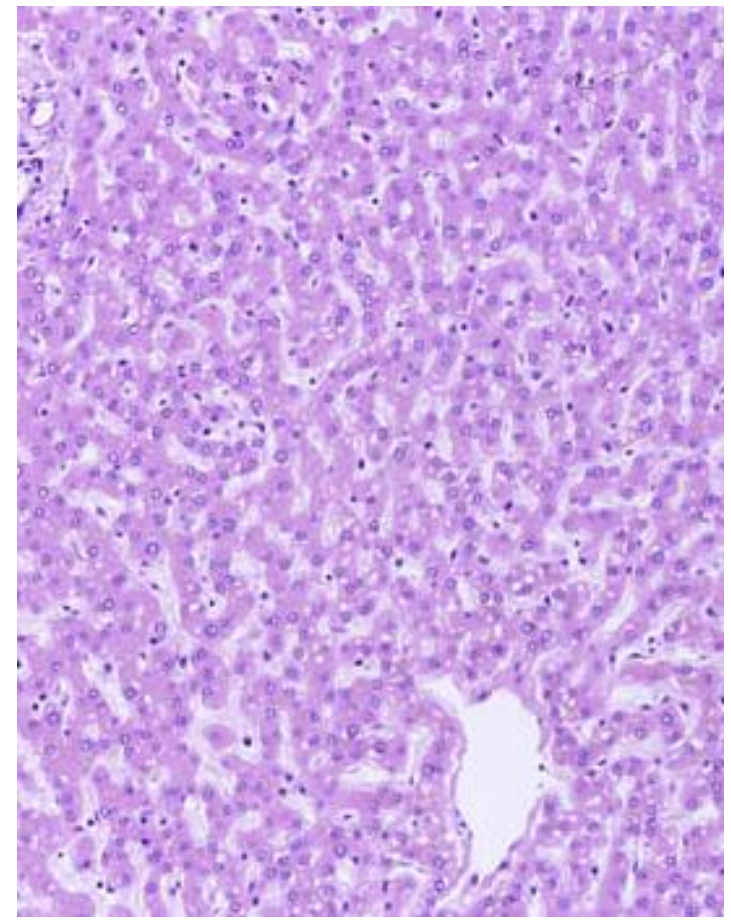

Microphotograph for group I: normal histoarcheticture

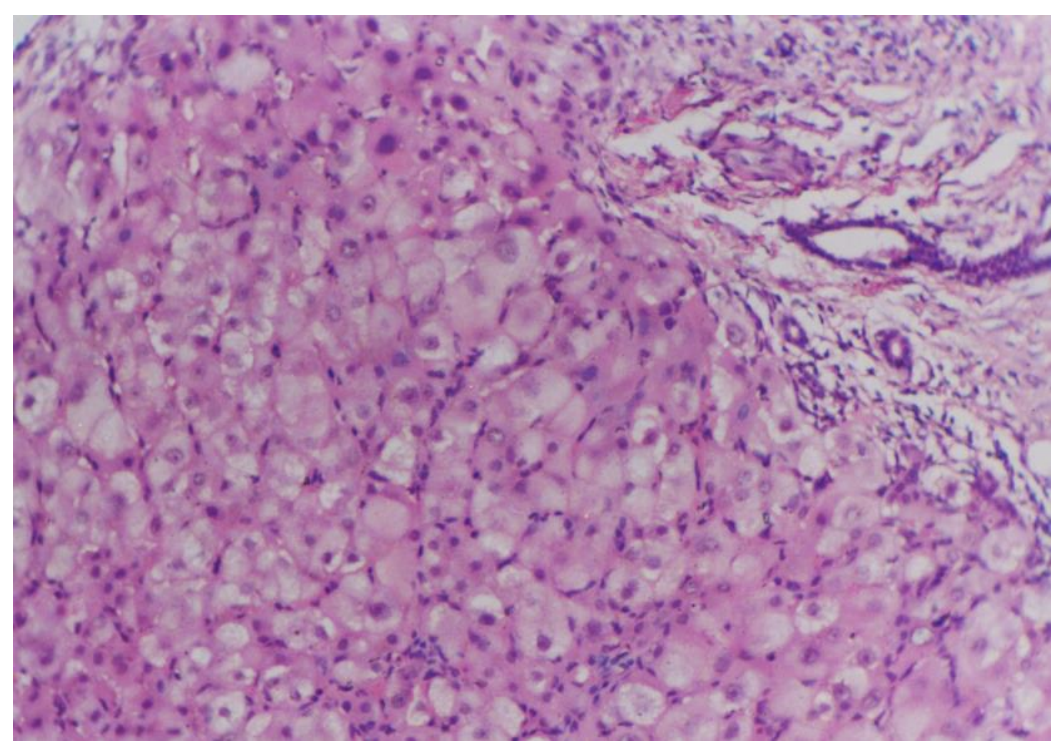

Microphotograph for group II: Mild interface activity, focal necrosis and lymphocytic infiltration of portal tract (H\&EX600) 


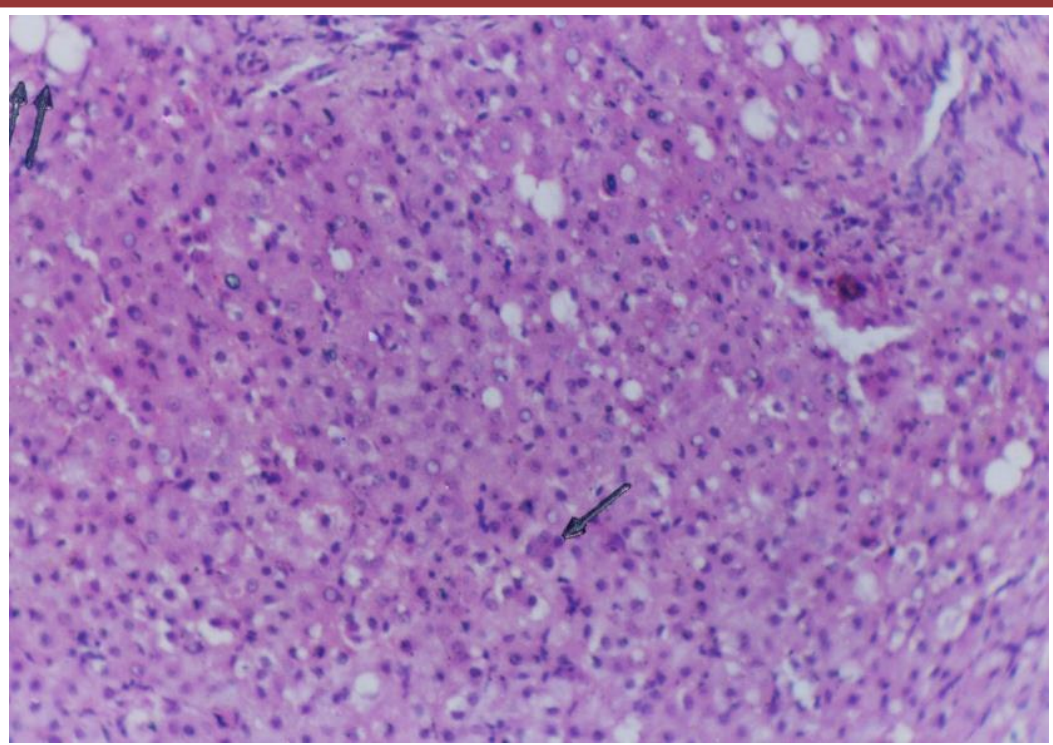

Microphotograph for group III: Mild lobular activity with spotty necrosis and focal steatosis. (H\&EX300)

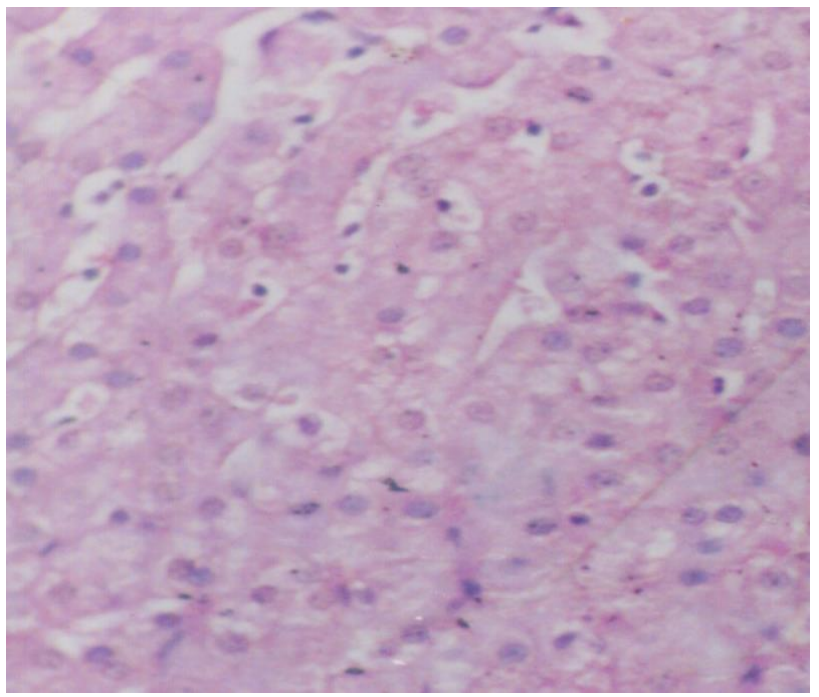

Microphotograph for group IV: Hepatic lobule is nearly normal. (H\&EX600)

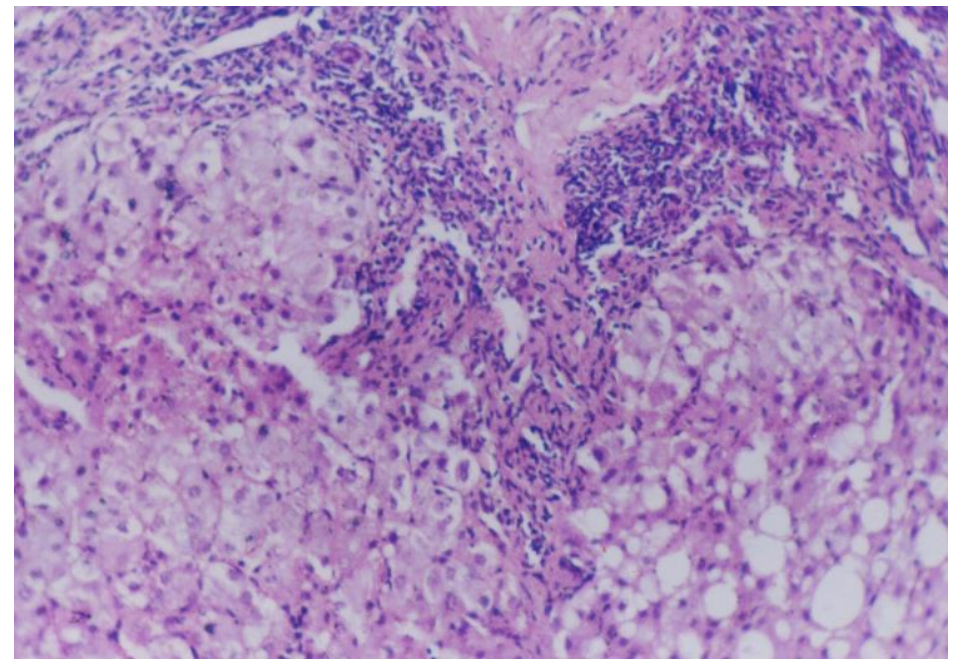

Microphotograph for group V: Severe interface activity with heavy lymphocytic infiltration periportal area and focal steatosis. (H\&EX300) 


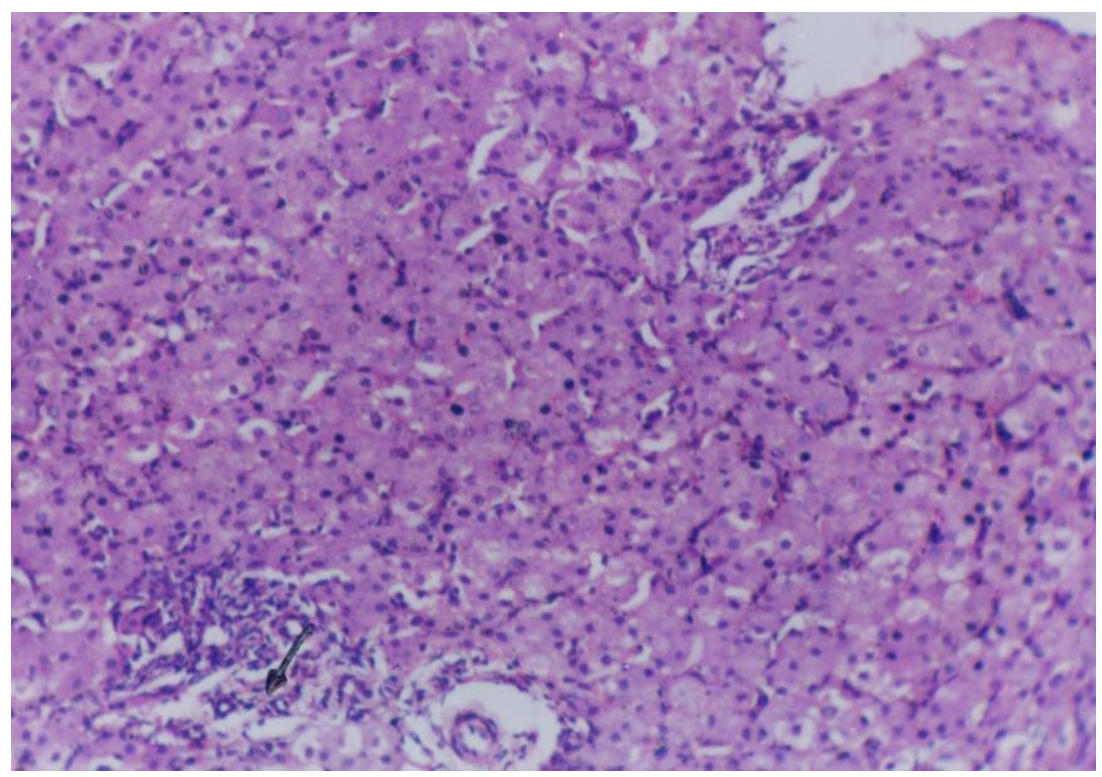

Microphotograph for group VI: Focal lobular mononuclear infiltrate and portal inflammation. (H\&EX300)

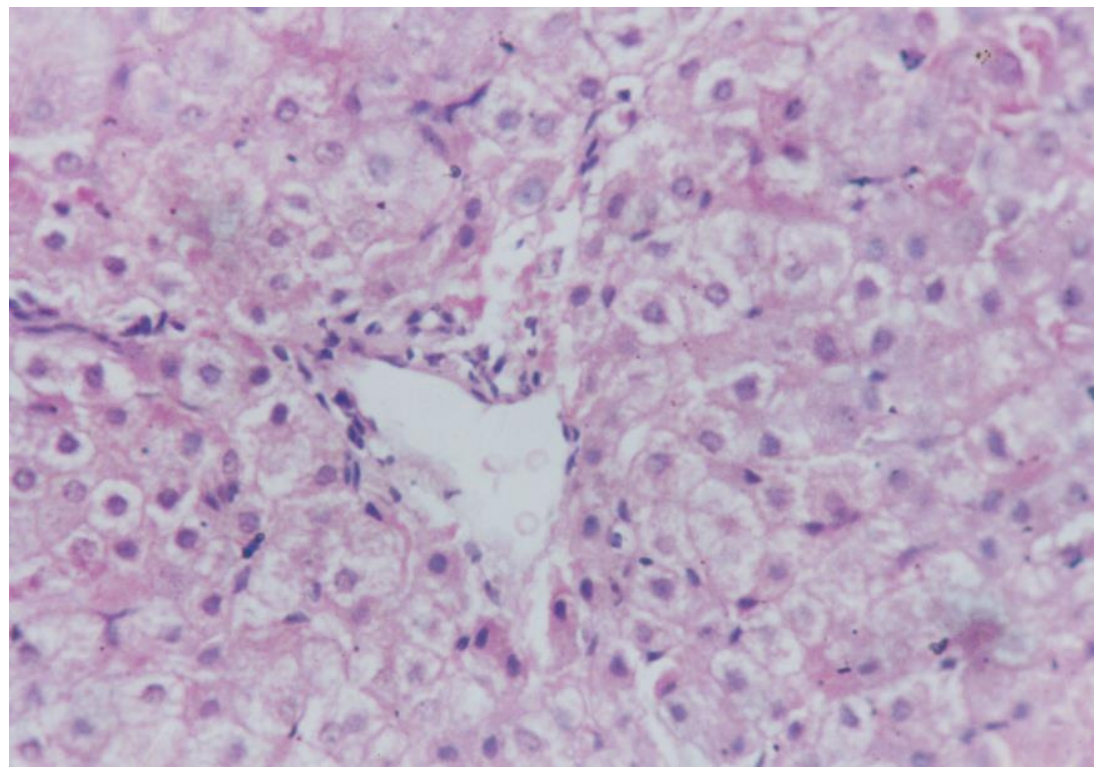

Microphotograph for group VII: Mild inflammatory reaction around the central vein (H\&EX600)

\section{DISCUSSION}

The results of the present study demonstrated that administration of atorvastatin in a dose of 20 and $80 \mathrm{mg} / \mathrm{kg}$ daily for one month produced dose-dependent, significant elevation of serum AST and ALT levels. Our histopathological findings showed that atorvastatin in a dose of $20 \mathrm{mg} / \mathrm{kg}$ have minimal hepatocyte degeneration while a dose of $80 \mathrm{mg} / \mathrm{kg}$ caused marked hepatocyte degeneration. Also, atorvastatin in a dose of 20 and $80 \mathrm{mg} / \mathrm{kg}$ daily for one month produced dose-dependent, significant elevation of SOD and CAT activities in the liver homogenates which indicate the presence of oxidative stress. These findings cope with that obtained by Malloy and Kane ${ }^{4}$ who reported that elevations of serum aminotransferase activity (up to three times normal) occur in some patients on statin therapy. Also, Clarke and Mills ${ }^{15}$ concluded that, atorvastatin can cause significant acute hepatotoxicity. These serious hepatic reactions tend to occur in females, over 60 years, and persistent elevation in serum transaminases in this group should prompt early review of the need to continue with atorvastatin therapy. 
In our results, groups treated with propolis 50 or $100 \mathrm{mg} / \mathrm{kg}$ with atorvastatin 20 or $80 \mathrm{mg} / \mathrm{kg}$ showed significant dose-dependent reduction of the serum levels of AST and ALT and the activities of SOD and CAT in the liver homogenate in relation those obtained in groups treated with atorvastatin alone. This means that propolis protected the liver from the oxidative stress occurred in groups treated with atorvastatin alone. Propolis treatment also reversed atorvastatin induced severe alterations in histoarcheticture of liver in a dose dependent manner.

These findings cope with Arjun et al. ${ }^{16}$ who found that propolis has hepatoprotective activity on D-galactosamine: tumor necrosis factor- $\alpha$ induced cell death in primary cultured mouse hepatocytes. Propolis contains more than 180 compounds including essential oils, flavinoids, phenolic acids and their esters. ${ }^{17}$ Also, El-Khatib et al. ${ }^{18}$ found that in isolated hepatocytes, aqueous propolis extract afforded protection against $\mathrm{CCl} 4$ induced injury as manifested by a decrease in the leakage of the cytosolic enzyme lactate dehydrogenase $(\mathrm{LDH})$, decreased generation of lipid peroxide and maintenance of cellular reduced glutathione (GSH) content. In principle, similar findings were observed in liver homogenates. They reported that aqueous propolis extract has in vivo hepatoprotective potential which could be attributed at least in part to the maintenance of cellular GSH content. The latter effect seems to play an important role in conserving the integrity of biomembranes as it was associated with a decrease in lipid peroxidation and reduced leakage of cytosolic LDH.

Also Bhadauria et al. ${ }^{19}$ demonstrated that propolis therapy produced duration-dependent protection, with maximal protection achieved at $24 \mathrm{~h}$ after $\mathrm{CCl}_{4}$ exposure. They believed that propolis in its natural form has general pharmacologic value and marked hepatoprotective potential because of its composition of minerals, flavonoids, and phenolic compounds.

Several studies demonstrated that, activation of nuclear factor (NF) kappa B by tumor necrosis factor is completely blocked with caffeic acid phenethyl ester (CAPE), a component of propolis, in a dose dependant manner. CAPE also inhibited NF kappa B activation induced by other inflammatory agents including propol esters, ceramide, hydrogen peroxide and okadaic acid. ${ }^{20}$

In conclusion, propolis has a hepatoprotective effect against the hepatotoxicity induced by atorvastatin. This effect may be at least in part due its powerful antioxidant effect. Further experimental and clinical studies are needed to confirm these results and its possible application for hepatic protection with patients on chronic satin therapy.

\section{ACKNOWLEDGMENTS}

The assistance of Dr. Rehab Karam, lecturer of biochemistry, faculty of medicine, Zagazig University is gratefully acknowledged.

\section{REFERENCES}

1- Bell LN, Chalasani N: Epidemiology of idiosyncratic drug-induced liver injury. Semin Liver Dis, 2009; 29: 337-347.

2- Adam D F, Alison B: Drug-induced liver injury. Medicine. 2011; 39, 9: 536-540.

3- Michael HD, Evan AS, Carlos AD, Donald B, Stuart RW, Robert HK: The Efficacy and Six-Week Tolerability of Simvastatin 80 and $160 \mathrm{mg} /$ Day. Am J Cardiol 1997; 79:38-42.

4- Malloy JM, Kane JP: Agents used in hyperlipidemia. In: Katzung BG, Masters SB, Trevor AJ (Eds), Basic\& Clinical Pharmacology. $12^{\text {th }}$ ed., Mc Graw Hill Medical, New York, USA. 2012; 619-633.

5- Kolankaya D, Selmanoglu G, Sorkun K, Salih B: Protective effects of Turkish propolis on alcohol induced serum lipid changes and liver injury in male rats. Food Chem. 2002; 78: 213-217.

6- Yousef MI, Kamel KI, Hassan MS, El-Morsy AM: Protective role of propolis against reproductive toxicity of triphenyltin in male rabbits. Food Chem. Toxicol. 2010; 48: 1846-1852.

7- Kumazawa S, Ahn MR, Fujimoto T, Kato M: Radical-scavenging activity and phenolic constituents of propolis from different regions of Argentina. Nat. Prod. Res., 2010; 24: 804-812.

8- Nader MA, El-Agamy DS, Suddek GM: Protective effects of propolis and thymoquinone on development of atherosclerosis in cholesterol-fed rabbits. Arch. Pharm. Res. 2010; 33: 637-643.

9- Shukla S, Bhadauria M, Jadon A: Effect of propolis extract on acute carbon tetrachloride induced hepatotoxicity.Indian J. Exp. Biol. 2004; 42(10): 993-7.

10- Garcia, GG, Miranda, HF, Noriega, V, Sierralta, F, Olavarría, L, Zepeda, RJ, Prieto, JC: Antinociception induced by atorvastatin in different pain models. Pharmacology, Biochemistry and Behavior. 2011; 100: 125-129

11- Reitman S, Frankel S: A colorimetric method for the determination of serum glutamic oxaloacetic and glutamic pyruvic transaminases. Am. J. Clin. Pathol. 1957; 28, 56-63

12- Marklund S, Marklund G: Involvement of the superoxide anion radical in the autooxidation of pyrogallol and a convenient assay for superoxide dismutase. Eur J Biochem. 1974; 47: 469-474.

13- Abei C: Catalase. In: Bergmeyer, HD (ed), Methods of Enzymatic analysis. Academic press, New York, Ny. 1974; 631-384. 
14- Kiernan J: Histological and histochemical methods. In: Theory and Practice of histological techniques. $3^{\text {rd }}$ ed. University of Western Ontario, London Ontario, Canada. 2001; 100-131.

15- Clarke AT, Mills PR: Brief Clinical Observation of Atorvastatin. Pharmacology, Biochemistry and Behavior. 2006; 100, 125-129.

16- Arjun HB, Yasuhiro TI, Ketut A, Katsumichi M, Dejair M, Alfredo AG, Shigetoshi K: Cytotoxic, hepatoprotective and free radical scavenging effects of propolis from Brazil, Peru, the Netherlands and China. Journal of Ethnopharmacology. 2000; 72: 239-246

17- Banskota AH, Tezuka Y, Prasain JK, Matsushige $\mathrm{K}$, Saiki I, Kadota S Chemical constituents of
Brazilian propolis and their cytotoxic activity. Journal of Natural Products. 1998; 61: 896-900.

18- El-Khatib AS, Agha AM, Mahran LG, Khayyal MT: Prophylactic effect of aqueous propolis extract against acute experimental hepatotoxicity in vivo. $\mathrm{Z}$ Naturforsch C. 2002; 57(3-4):379-85.

19- Bhadauria M, Nirala SK, Shukla S: Durationdependent hepatoprotective effects of propolis extract against carbon tetrachloride-induced acute liver damage in rats. Adv Ther. 2007; 24(5):113645.

20- Seo KW, Park M, Song YJ, Kim S, Yoon KR: The protective effect of propolis on hepatic injury and its mechanism. Phytother. Res. 2003; 17(3): 250253. 